\title{
PENGARUH PEMBERIAN PbB ASETAT DOSIS TINGGI TERHADAP KETEBALAN MIELIN N. ISCHIADICUS TIKUS PUTIH (RATTUS NORVEGICUS)
}

\section{THE EFFECT OF HIGH DOSE LEAD ACETATE ON THE THICKNESS OF MYELIN N.ISCHIADICUS OF RATTUS NORVEGICUS}

\author{
Ulfa Elfiah \\ Laboratorium Anatomi Fakultas Kedokteran Universitas Jember
}

\begin{abstract}
Lead is commonly used in batteries, electrical cabel, and pipe manufacture. Despite its usefulness, lead has some sentrimental effects such as intoxication by chronic lead exposure results in peripheral neuropathy. This research was to determine the effect of oral administration of lead acetate to the thickness of mielin n.ischiadicus. The post test only control group design was used assigning. Thirty male rats into five groups of treatment. Aquadest was administered to group I. Lead acetate with doses of rats were sacrificed: $65,125,250$, and $500 \mathrm{mg} / \mathrm{kg} b \mathrm{w} /$ day were administered to group II, III, IV, and V. Lead acetate were given daily for 10 weeks and then to make histological preparations from n.ischiadicus using osmic acid as fixative and toloidin blue as staining agents. The results research showed that oral administration of lead acetate affected the thickness of mielin with higher does resulted in thinner mielin.
\end{abstract}

Keywords: thickness of mielin, lead acetate, oral

\section{PENDAHULUAN}

Timbal mempunyai kegunaan bagi kehidupan manusia misalnya timbal digunakan dalam industri kabel, baterai, insektisida, bahan pembuat pipa (1). Akan tetapi di sisi lain timbal dalam jumlah kadar tertentu dapat menimbulkan efek negatif. Pada sistem saraf pusat timbal dapat menyebabkan encelopati yang secara klinis ditandai dengan munculnya ataksia, stupor, koma, dan kejang-kejang. Sedangkan pada sistem saraf tepi keracunan timbal dapat menyebabkan neuropati perifer yang secara klinis ditandai adanya wrist drop dan foot drop (2). Kerusakan pada sistem saraf khususnya pada anak-anak juga disertai dengan penurunan intelligence quotient (IQ) yang berakibat anak-anak cenderung lamban dalam berpikir dan tidak cerdas.

Adanya efek toksik timbal yang cukup berbahaya terhadap sistem saraf ini maka perlu adanya suatu penelitian baik studi toksisitas terhadap manusia di lapangan maupun studi eksperimental di laboratorium. Penelitian ini merupakan merupakan jenis penelitian eksperimental yang bertujuan untuk mengetahui ada tidaknya pengaruh $\mathrm{Pb}$ asetat dengan berbagai tingkatan dosis terhadap ketebalan mielin n.ischiadicus tanpa melihat perubahan ultrastruktur yang ada. Hasil yang diperoleh pada hewan uji ini diharapkan dapat menjadi dasar untuk memperkirakan adanya pengaruh $\mathrm{Pb}$ asetat terhadap sistem saraf tepi manusia sehingga masyarakat lebih berhati-hati dalam menggunakan segala sesuatu yang berhubungan dengan timbal dan pemerintah

Jurnal Kedokteran Brawijaya, Vol. XXIII, No. 1, April 2007 Korespondensi: Ulfa Elfiah; Laboratorium Anatomi Fakultas Kedokteran Universitas Jember; email: elfiah@yahoo.com bersama semua pihak terkait dapat lebih bijaksana dalam menangani masalah limbah $\mathrm{Pb}$ (timbal).

\section{METODE}

Rancangan penelitian ini menggunakan post test only control group design. Sampel penelitian sebanyak 30 ekor tikus putih, umur 7 minggu dengan berat rerata 80-100 gram. Sampel secara acak dibagi dalam 5 kelompok, yaitu: 1). $P 1$ adalah kelompok kontrol yang mendapatkan aquades sebagai plasebo, 2). P2 adalah kelompok perlakuan yang mendapatkan $\mathrm{Pb}$ asetat peroral dosis $65 \mathrm{mg} / \mathrm{kgbb} / \mathrm{hr}, 3)$. P3 adalah kelompok perlakuan yang mendapatkan $\mathrm{Pb}$ asetat peroral dosis $125 \mathrm{mg} / \mathrm{kgbb} / \mathrm{hr}, 4$ ). P4 adalah kelompok perlakuan yang mendapatkan $\mathrm{Pb}$ asetat peroral dosis 250 $\mathrm{mg} / \mathrm{kgbb} / \mathrm{hr}$, 5). P5 adalah kelompok perlakuan yang mendapatkan $\mathrm{Pb}$ asetat peroral dosis $500 \mathrm{mg} / \mathrm{kg} \mathrm{bb} / \mathrm{hr}$.

$\mathrm{Pb}$ asetat diberikan saat tikus putih berumur 8 minggu dan pemberian diberikan selama 10 minggu menggunakan sonde. Pada akhir masa perlakuan tikus putih dietanasi kemudian diambil n.ischiadicus extremitas posterior dextra $1 \mathrm{~cm}$ dari bagian pangkal. Selanjutnya dibuat sediaan histologis pada potongan melintang dengan teknik pewarnaan modifikasi pra TEM (Transmission Electron Microscope) dengan asam osmik sebagai fiksasi dan toloidin blue sebagai pewarna. Teknik ini disebut Pra-TEM karena sediaan yang dibuat hanya sampai pada pengirisan tebal dengan ultra mikrotom selanjutnya sampel diukur menggunakan mikrometer yang sudah ditera di bawah mikroskop cahaya dengan pembesar 450x. Hasil akhir pengukuran dalam satuan milimeter yang selanjutnya dirubah dalam satuan mikrometer. 
Selain itu pemilihan teknik ini sesuai dengan tujuan penelitian yang hanya untuk mengetahui efek atau pengaruh timbal terhadap sistem saraf tepi tanpa melihat perubahan struktur secara ultramikroskopik.

Evaluasi perubahan yang terjadi adalah dengan cara mengukur diameter serat saraf dan diameter akson untuk dapat menentukan ketebalan mielin. Untuk mengurangi bias pengamatan dilakukan pada 4 lapangan pandang pada posisi jam 12, 3, 6, dan 9 untuk setiap ulangan. Pada setiap lapangan pandang dihitung 10-15 serat saraf. Sehingga hasil pengukuran merupakan rerata dari kelima lapangan pandang. Kemudian hasil pengukuran masing-masing dosis perlakuan diambil reratanya untuk ditabulasi kemudian dibandingkan dengan uji anova pada taraf kepercayaan 0,05 . Jika ada perbedaan pengaruh perlakuan yang bermakna maka dilanjutkan dengan uji beda nyata terkecil.

\section{HASIL PENELITIAN}

Berdasarkan hasil pengamatan di bawah mikroskop pembesarn 450x didapatkan data sebagai berikut:

Berdasarkan Tabel 1 tampak nilai rerata diameter serat saraf semakin kecil dengan bertambahnya dosis. Pada kontrol ukuran rerata diameter serat saraf kurang lebih sebesar $4 \mu \mathrm{m}$ kemudian pada dosis $65 \mathrm{mg} / \mathrm{kgbb} / \mathrm{hr}$ menjadi setengahnya bahkan hampir ukurannya menjadi sepertiganya pada dosis $500 \mathrm{mg} / \mathrm{kgbb} / \mathrm{hr}$ bila dibandingkan dengan ukuran diameter serat saraf kontrol. Perubahan ukuran ini tampak jelas pada gambaran mikrokopik yang tampak pada Gambar 1 sampai 5. Diametre serat saraf padaa gambaran mikroskopik meliputi myelin dan akson.

Pada Tabel 2 terlihat ukuran diameter akson tidak menunjukkan perubahan yang berarti, rerata ukurannya berkisar anatra 1,6 $\mu \mathrm{m}$ baik kontrol maupun pada tikus yang mendapatkan $\mathrm{Pb}$ asetat dosis 65, 125, 250, dan $500 \mathrm{mg} / \mathrm{kgbb}$. Gambaran akson ini tampak sebagai bagian yang berwarma putih dikelilingi oleh bagian yang berwarna gelap sebagaimana tampak pada gambar hasil pemeriksaan dibawah mikroskop (lihat Gambar 1-5).

Gambaran myelin merupakan bagian yang berbentuk seperti cincin pada gambaran mikroskopik yang sebenarnya merupakan hasil penggunaan diameter serat saraf dan diameter akson. Hasil pengukuran rerata ketebalan mielin seperti tampak pada Tabel 3 yang menunjukkan pola hampir sama dengan Tabel 1, yaitu ukurannya mengalami perubahan, semakin besar dosis $\mathrm{Pb}$ asetat yang diberikan semakin kecil ukuran ketebalan mielinnya.

Tabel 1. Rerata diameter serat saraf $n$.ischiadicus

\begin{tabular}{|c|c|c|c|c|c|}
\hline \multirow[b]{2}{*}{ No Sampel } & \multicolumn{5}{|c|}{ Diameter serat saraf } \\
\hline & $\mathrm{P} 1=\mathrm{Kontrol}(\mu \mathrm{m})$ & $\mathrm{P} 2=65 \mathrm{mg} / \mathrm{kgbb} / \mathrm{hr}(\mu \mathrm{m})$ & $\mathrm{P} 3=125 \mathrm{mg} / \mathrm{kgbb} / \mathrm{hr}(\mu \mathrm{m})$ & $\mathrm{P} 4=250 \mathrm{mg} / \mathrm{kgbb} / \mathrm{hr}(\mu \mathrm{m})$ & $\mathrm{P} 5=500 \mathrm{mg} / \mathrm{kgbb} / \mathrm{hr}(\mu \mathrm{m})$ \\
\hline 1 & 4,480 & 2,690 & 2,201 & 1,999 & 1,862 \\
\hline 2 & 4,318 & 2,676 & 2,024 & 2,000 & 1,732 \\
\hline 3 & 4,102 & 2,654 & 2,181 & 1,997 & 1,732 \\
\hline 4 & 4,183 & 2,676 & 2,091 & 1,889 & 1,709 \\
\hline 5 & 4,048 & 2,700 & 2,158 & 1,997 & 1,734 \\
\hline 6 & 3,967 & 2,700 & 2,249 & 1,889 & 1,862 \\
\hline Rerata+SD & $4,182 \pm 0,190$ & $2,683 \pm 1,77 \mathrm{E}-02$ & $2,151+0,1317$ & $1,963+0,108$ & $1,735+0,116$ \\
\hline
\end{tabular}

Keterangan:

$\mathrm{P} 1$ : kelompok kontrol yang mendapatkan aquades sebagai plasebo

$\mathrm{P} 2$ : kelompok perlakuan yang mendapatkan $\mathrm{Pb}$ asetat peroral dosis $65 \mathrm{mg} / \mathrm{kgbb} / \mathrm{hr}$

P3: kelompok perlakuan yang mendapatkan $\mathrm{Pb}$ asetat peroral dosis $125 \mathrm{mg} / \mathrm{kgbb} / \mathrm{hr}$

$\mathrm{P} 4$ : kelompok perlakuan yang mendapatkan $\mathrm{Pb}$ asetat peroral dosis $250 \mathrm{mg} / \mathrm{kgbb} / \mathrm{hr}$

$\mathrm{P} 5$ : kelompok perlakuan yang mendapatkan $\mathrm{Pb}$ asetat peroral dosis $500 \mathrm{mg} / \mathrm{kgbb} / \mathrm{hr}$

Tabel 2. Rerata diameter akson serat saraf $n$.ischiadicus

\begin{tabular}{|c|c|c|c|c|c|}
\hline \multirow[b]{2}{*}{ No Sampel } & \multicolumn{5}{|c|}{ Diameter akson serat saraf } \\
\hline & $\overline{P 1=k o n t r o l}(\mu \mathrm{m})$ & $\mathrm{P} 2=65 \mathrm{mg} / \mathrm{kgbb}(\mu \mathrm{m})$ & $\mathrm{P} 3=125 \mathrm{mg} / \mathrm{kgbb}(\mu \mathrm{m})$ & $\mathrm{P} 4=250 \mathrm{mg} / \mathrm{kgbb}(\mu \mathrm{m})$ & $\mathrm{P} 5=500 \mathrm{mg} / \mathrm{kgbb}(\mu \mathrm{m})$ \\
\hline 1 & 1,680 & 1,507 & 1,664 & 1,574 & 1,687 \\
\hline 2 & 1,645 & 1,507 & 1,574 & 1,574 & 1,664 \\
\hline 3 & 1,642 & 1,664 & 1,664 & 1,754 & 1,664 \\
\hline 4 & 1,650 & 1,664 & 1,619 & 1,754 & 1,664 \\
\hline 5 & 1,670 & 1,687 & 1,597 & 1,596 & 1,574 \\
\hline 6 & 1,670 & 1,642 & 1,574 & 1,596 & 1,574 \\
\hline Rerata+ SD & $1,659+1,58 \mathrm{E}-02$ & $1,612+0,131$ & $1,615+4,12 \mathrm{E}-02$ & $1,641+0,134$ & $1,639+0,126$ \\
\hline
\end{tabular}


Tabel 3. Rerata ketebalan mielin serat saraf $\boldsymbol{n}$.ischiadicus

\begin{tabular}{|c|c|c|c|c|c|}
\hline \multirow[b]{2}{*}{ No Sampel } & \multicolumn{5}{|c|}{ Ketebalan mielin serat saraf } \\
\hline & P1=kontrol $(\mu \mathrm{m})$ & $\mathrm{P} 2=65 \mathrm{mg} / \mathrm{kgbb}(\mu \mathrm{m})$ & $\mathrm{P} 3=125 \mathrm{mg} / \mathrm{kgbb}(\mu \mathrm{m})$ & $\mathrm{P} 4=250 \mathrm{mg} / \mathrm{kgbb}(\mu \mathrm{m})$ & $\mathrm{P} 5=500 \mathrm{mg} / \mathrm{kgbb}(\mu \mathrm{m})$ \\
\hline 1 & 2,366 & 1,010 & 0,537 & 0,425 & 0,175 \\
\hline 2 & 2,676 & 1,031 & 0,450 & 0,426 & 0,068 \\
\hline 3 & 2,483 & 1,012 & 0,517 & 0,243 & 0,068 \\
\hline 4 & 2,464 & 1,026 & 0,472 & 0,235 & 0,045 \\
\hline 5 & 2,699 & 1,030 & 0,561 & 0,401 & 0,260 \\
\hline 6 & 2,325 & 1,030 & 0,675 & 0,293 & 0,288 \\
\hline Rerata+SD & $2,522 \pm 0,189$ & $1,071 \pm 0,132$ & $0,535+0,117$ & $0,321 \pm 0,118$ & $9,58 \mathrm{E} 02+6,53 \mathrm{E}-02$ \\
\hline
\end{tabular}

Gambaran Diameter serat saraf, Akson, dan Mielin Pada Setiap Perlakuan:

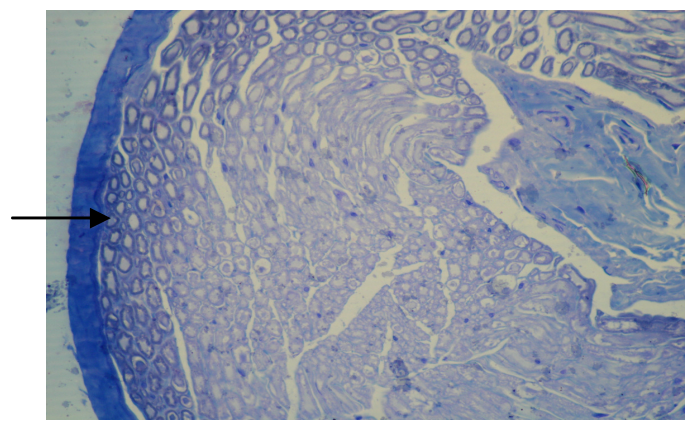

Gambar 1.Gambar serat saraf, akson, dan mielin pada kelompok P1 yaitu kelompok kontrol yang hanya mendapatkan plasebo dibawah mikroskop cahaya pembesaran 450x. Mielin tampak seperti cincin berwarna biru tebal, akson bagian putih ditengah cincin, serat saraf adalah meliputi mielin dan akson

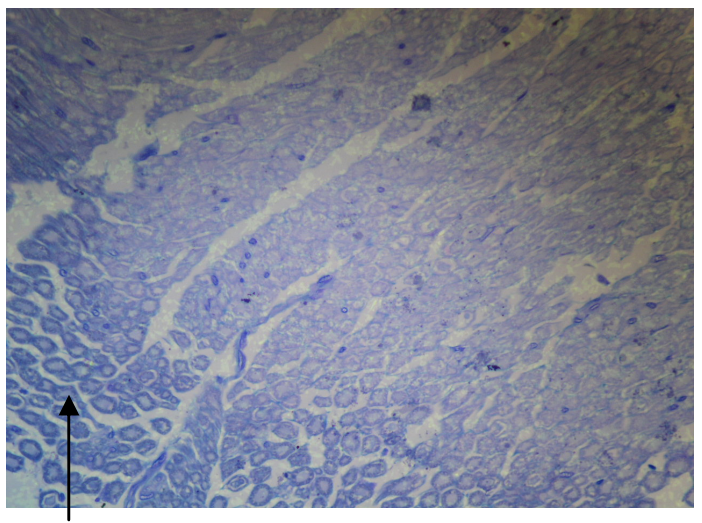

Gambar 2. Gambar serat saraf, akson, dan mielin pada kelompok P2 yaitu kelompok yang mendapatkan dosis $\mathrm{Pb}$ asetat $65 \mathrm{mg} / \mathrm{kgbb}$ dibawah mikroskop cahaya pembesaran 450x. Mielin tampak seperti cincin berwarna biru tebal, akson bagian putih ditengah cincin, serat saraf adalah meliputi mielin dan akson

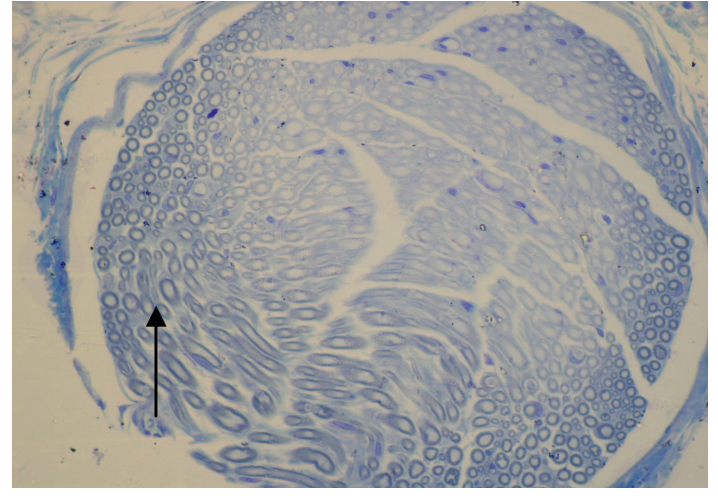

Gambar 3. Gambar serat saraf, akson, dan mielin pada kelompok $\mathrm{P} 3$ yaitu kelompok yang mendapatkan dosis $125 \mathrm{mg} / \mathrm{kgbb}$ dibawah mikroskop cahaya pembesaran $450 x$. Mielin tampak seperti cincin berwarna biru tebal, akson bagian putih ditengah cincin, serat saraf adalah meliputi mielin dan akson

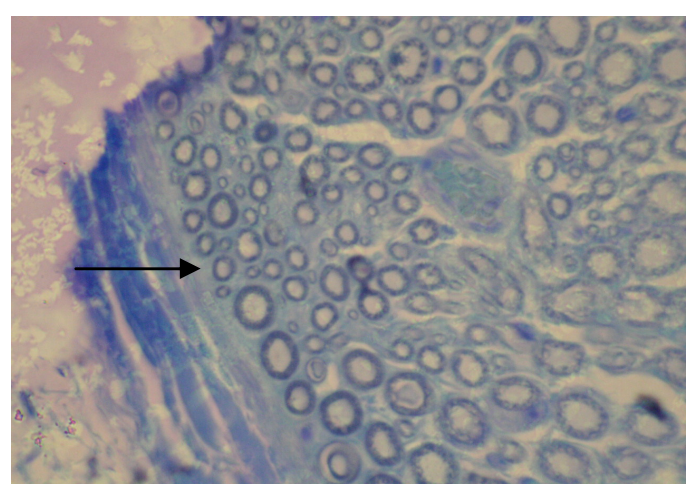

Gambar 4.Gambar serat saraf, akson, dan mielin pada kelompok P4 yaitu kelompok yang mendapatkan Dosis $250 \mathrm{mg} / \mathrm{kgbb}$ dibawah mikroskop cahaya pembesaran $450 x$. Mielin tampak seperti cincin berwarna biru tebal, akson bagian putih ditengah cincin, serat saraf adalah meliputi mielin dan akson 


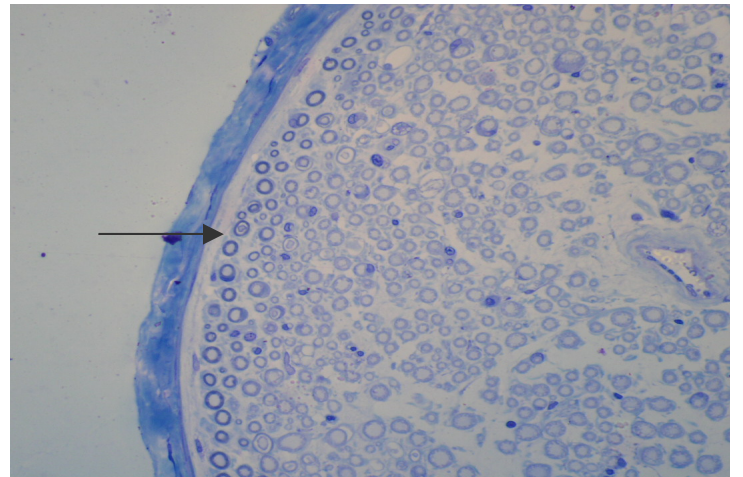

Gambar 5.Gambar serat saraf, akson, dan mielin pada kelompok P5 yaitu kelompok yang mendapatkan dosis $500 \mathrm{mg} / \mathrm{kgbb}$ dibawah mikroskop cahaya pembesaran $450 x$. Mielin tampak seperti cincin berwarna biru tebal, akson bagian putih ditengah cincin, serat saraf adalah meliputi mielin dan akson

\section{DISKUSI}

Umumnya pada tikus reaksi intoksikasi terhadap $\mathrm{Pb}$ asetat lebih dahulu mengenai saraf perifer dibandingkan saraf pusat. Alasan ini dikaitkan dengan posisi anatomis dari saraf perifer yang umumnya berjalan secara bersamaan dengan pembuluh darah sehingga penumpukan zat toksik lebih mudah dan lebih awal dibandingkan sistem saraf pusat. Kerusakan yang dialami oleh n.ischiadicus ini dikarenakan adanya proses patologi. Proses ini sebagai bentuk reaksi intoksikasi terhadap $\mathrm{Pb}$ asetat. Adapun bentuk reaksi intoksikasi pada saraf perifer ini berupa reaksi predominan demielinisasi segmental (2). Pada proses demielinisasi akibat keracunan timbal ini, sel Schwann dapat mengalami kerusakan secara langsung. Degenerasi sel Schwann terjadi karena adanya perubahan ultrastruktur, yaitu 1). diduga berhubungan dengan adanya gangguan transport $\mathrm{Ca}^{2+}$ dan 2). adanya edema sel Schwann (1). Biasanya kerusakan ini dimulai pada daerah sekitar nodus ranvier. Kerusakan yang dialami oleh sel Schwann akan berpengaruh terhadap selubung mielin karena selubung mielin berasal dari tumpukan-tumpukan membran sel Schwann akibat sitoplasmanya yang terperas dan tersisa dililitan terluar (4). Akibatnya sarung mielin tidak terbentuk. Proses lain yang mungkin terjadi akibat intoksikasi timbal yaitu langsung mempengaruhi selubung mielin yang sudah ada dengan cara mengganggu struktur membrannya. Sehungga selubung mielin mengalami proses degenarasi terlepas dari akson $(1,4)$.

Pada beberapa penelitian dengan menggunakan mikroskop electron sebagai alat untuk mempelajari tentang pengaruh pemberian $\mathrm{Pb}$ secara kronik pada minuman tikus juga disebutkan bahwa terjadinya perubahan struktur mielin sebagai akibat adanya perubahan biofisikal dan biokemis. Perubahan ini ditunjukkan dengan adanya perubahan kepadatan membran mielin yang diukur menggunakan spectrofluorometry dan electron paramagnetic resonance (EPR) (5). Bahkan pada penelitian yang berbeda disebutkan $\mathrm{Pb}$ dapat mempengaruhi ekspresi gen pada protein struktural mielin sistem saraf pusat dan keadaan ini diduga mempengaruhi komposisi protein mielin yang dibentuk (6).

Pada penelitian ini bukti adanya kerusakan ini dapat dilihat dari perubahan rerata ukuran diameter ketebalan mielin seperti yang tampak pada tabel 3 yaitu rerata ketebalan mielin mempunyai kecenderungan makin menurun. Kondisi ini juga dibuktikan dari hasil uji LSD yang menyatakan bahwa ada perbedaan yang sangat bermakna $(p<0,05)$ antara kelompok kontrol dengan masing-masing dosis paparan $\mathrm{Pb}$ asetat. Hal ini berarti semakin tinggi dosis yang diberikan semakin tipis ukuran ketebalan mielin n.ischiadicus dan hasil ini juga menunjukkan bahwa semakin tinggi dosis yang diberikan tingkat kerusakan mielin yang dialami oleh n.ischiadicus semakin parah.

Ketebalan mielin ini sangat mempengaruhi ukuran diameter serat saraf. Dengan demikian semakin tipis mielin maka ukuran diameter serat saraf n.ischiadicus semakin kecil begitu sebaliknya. Keadaan ini dapat ditunjukkan dengan hasil rerata diameter serat saraf $n$.ischiadicus (tabel 1) yang juga mempunyai kecenderungan makin menurun seiring dengan peningkatan dosis dengan kata lain semakin tinggi dosis $\mathrm{Pb}$ asetat yang diberikan diameter serat saraf n.ischiadicus semakin kecil. Secara histologi ukuran normal diameter serat saraf bermielin mempunyai ukuran diameter antara 2-17 $\mu \mathrm{m}$ (4). Apabila dibandingkan dengan ukuran ini maka ukuran rerata diameter serat saraf tikus yang mendapatkan paparan $\mathrm{Pb}$ asetat dosis 65 dan $125 \mathrm{mg} / \mathrm{kgbb}$ ukurannya masih dalam kisaran diameter serat saraf bermielin meskipun lebih kecil dari ukuran kelompok kontrol. Sedangkan untuk tikus yang mendapatkan dosis 250 dan $500 \mathrm{mg} / \mathrm{kgbb}$ ukuran diameternya lebih rendah dari ukuran normal.

Kerusakan yang terjadi pada mielin n.ischiadicus ini tidak hanya dipengaruhi oleh dosis $\mathrm{Pb}$ asetat yang diberikan tetapi faktor umur atau usia dari hewan coba juga menentukan berat ringannya kerusakan. Susunan saraf pada hewan muda umumnya sangat rentan terhadap efek toksik dari timbal atau $\mathrm{Pb}$ dibandingkan dengan susunan saraf pada hewan dewasa yang relatif resisten. Hal ini disebabkan ketidakmatangan sistem pembuluh darahnya sehingga timbal organik lebih mudah menembus sawar. Pada penelitian ini hewan coba mendapatkan paparan $\mathrm{Pb}$ asetat pada usia 8 minggu, usia ini merupakan usia dewasa untuk tikus putih. Sehingga kerusakan yang dialami oleh hewan coba pada penelitian ini tidak seberat bila $\mathrm{Pb}$ asetat diberikan pada usia immature $(1,3)$. Keadaan ini dapat terlihat dari perubahan diameter serat saraf dan ketebalan mielin yang menunjukkan penurunan dratis saat dosis 
menjadi 250 dan $500 \mathrm{mg} / \mathrm{kg}$ bb. Sedangkan dosis dibawahnya belum menunjukkan perubahan yang berarti bila dibandingkan dengan rerata diameter serat saraf dan ketebalan mielin kontrol.

Selain dosis dan cara pemaparan faktor lain yang ikut menentukan berat ringannya kerusakan pada proses intoksokasi adalah lama pemaparan. Disebutkan bahwa lama pemaparan mempunyai korelasi yang sama seperti dosis dan cara pemaparan, semakin lama $\mathrm{Pb}$ asetat dipaparkan konsentrasinya dalam suatu jaringan semakin tinggi (8). Sehingga semakin tinggi konsentrasinya dalam jaringan maka kerusakan organ semakin berat.

Sementara itu dari hasil pengamatan didapatkan rerata diameter akson (tabel 2) tidak menunjukkan perubahan ukuran dengan semakin bertambahnya dosis. Kondisi ini menunjukkan bahwa pemberian $\mathrm{Pb}$ asetat kronik pada hewan coba hanya menyebabkan proses demielinisasi tanpa menyebabkan proses degenerasi dari akson. Dengan demikian kerusakan yang dialami oleh tikus putih dengan $\mathrm{Pb}$ asetat kurang bervariasi bila dibandingkan dengan manusia sebagaimana diungkapkan oleh Underwood (1992) dalam penelitiannya (7).

Selain pemeriksaan morfologik untuk mengetahui lesi pada saraf perifer akibat proses intoksikasi dapat dilakukan dengan menggunakan alat electrophysiology yang mampu mengukur kecepatan konduksi saraf sehingga disfungsi saraf motorik secara klinik dapat didiagnosis. Cara ini dapat diterapkan untuk penelitian langsung pada manusia di lapangan (9).

Dari hasil dan diskusi diatas dapat disimpulkan bahwa Pengaruh pemberian $\mathrm{Pb}$ asetet dengan berbagai tingkatan dosis dapat menyebabkan perubahan ukuran diameter serat saraf dan ketebalan mielin tanpa menyebabkan perubahan ukuran diameter akson. Semakin tinggi dosis yang diberikan ukuran diameter serat saraf makin kecil dan ketebalan mielin makin tipis.

\section{DAFTAR KEPUSTAKAAN}

1. Lu FC. Toksikologi Dasar, Azas, Organ Sasaran dan Penilaian Resiko. Edisi Kedua. Jakarta: Penerbit UI. 1995; 224235.

2. Cassarett LJ and Doulls. The Basic science of Poison. Fifth Edition. USA: The Mcgraw-hill Companies. 1999

3. Anderson WAD. Anderson'Patology. Eighth edition. St.Louis, Toronto, Princenton: The C. V. Mosby Company. 1985.

4. Underwood JCE. General and Systematic Patology. Churchill Livingstone: Edinburgh. 1992.

5. Dabrowska-Bouta B, Sulkowski G, Bartosz G, Walski M, Rafalowska U. Crhronic lead intoxication affects the myelin membrane status in the central nervous system of adult rats. J.Mol Neurosci 1999 aug-Oct; 13 (1-2): 127-139. Diakses tanggal 8 Juni 2006.

6. Zawia NH, Harry GJ. Exposure to lead- acetate modulates the developmental expression of myelin genes in the rat frontal lobe. Int J Dev Neurosci.1995 Oct; 13 (6): 639-644. Diakses tanggal 8 Juni 2006

7. Macsween Roderick NM, Whaley Keith. Muir's textbook of Patology. Thirteeth edition. Edward Arnold, Britain. 1992.

8. Bjorklund Hakan, Lind Birger, Piscacator Magnus, Hoffer Barry, Olson Lars. Lead, zinc, and Copper Levels in Intraocular Brain Tissue Grafts, Brain, and Blood of Lead-Exposure Rats. Toxicology and Applied Pharmacology. New York: Academic Press. 1981; 60.

9. Mykkanen HM, Dickerson JW, and Lancaster MC. Effect of age on tissue distribution of lead in rats. Toxicology Applied Pharmacology. 1979; 51, 447-454. 